\title{
Effect of Using Some Proprioceptive Neuromuscular Facilitation Techniques (PNF) on the Motor Range of Joints and the Level of Skill Performance of Handball Goalkeepers Ranya Mohamed Saeed Mahmoud
} Assistant Professor, Department of Training of Physical Sports, Faculty of Physical Education for Girls in Cairo - Helwan University - Egypt.

\section{Abstract}

The objective of this study was to identify the effect of applying some proprioceptive neuromuscular facilitation (PNF) techniques on motor range of (shoulder. spinal column. trunk. pelvis and foot) joints operating in handball goalkeeper skills and their level of skill performance. The researcher applied the experimental method by using one experimental group together with the pre and post-measurement to a sample of (10) goalkeepers of young female handball players of Zamalek Sporting Club born in 2006. Exercises lasted (3) months by (3) training units per week of a total of (36) training units. The researcher also used physical and skill performance tests. Results showed that stretch exercises by using some proprioceptive neuromuscular facilitation (PNF) techniques led to improving the motor range of the operating joints and the level of skill performance of young female handball goalkeepers.

\section{Research terminologies:}

Flexibility. elasticity. proprioceptive neuromuscular facilitation. handball goalkeeper. skills of handball goalkeeper.

\section{Introduction and research problem:}

Flexibility is one of the essential physical fitness components and means the motor range of the joint. It is measured by the maximum contraction and extension of the joint and expressed by the degree of angle or a line measured in centimeter. Flexibility is different from other physical fitness components in terms of its relation with functional properties of the motor system as it is related to the nature of joints. the status of girdles. tendons and muscles operating around this joint in respect of the degree of its tension or its relaxation and its degree of elasticity (Omar: 2009).

It is considered as one of the most important physical abilities affecting results of competitions. Insufficiency of flexibility of joints leads to curb the range of motion and consequently. reduces the efficiency of technical performance of skills and the ability of the player to use his capabilities in terms of strength. speed and coordination leading to lowering effort saved (Khaled: 2013)(Hartley:2001). Abo Al-Ela Abdel Fattah (2004) confirmed the correlation of flexibility with other physical properties. planning and skill performance as well since improving the skill performance in the majority of physical activities would depend on some rated flexibility. In a lot of physical activities the range of motion of joints involves as an essential factor for its success.

Nariman Al-Khatib et. al.. (2003) indicated that the skill performance would 
effect on the motor range of involved joints in respect of the effectiveness of performance or the extent of injuries the player may expose related to the positive. negative. increasing or decreasing effect of the motor range. Also the extra range in any joint would make it be dislocated under the effect of external resistances and hence. increasing the motor range of important joints associated with the specialized sport should be the first goal of the coach.

Kathy Stevens (2004) added that muscular stretch exercises aiming at increasing flexibility would help correct several errors and defects of technical performance that would consequently effect on the lateness and lowering the level in general and that would consider as an enough reason to consider muscular stretch programs built on scientific bases and that was confirmed by Joke Kekonen. (2006) that despite of applying stretch exercises aiming at improving flexibility. the major researches studying the effect of this improvement on performance would be few. The major studies discussed methods of increasing flexibility or identifying the relationship between occurring the injury and flexibility. As for the study of the effect of stretch exercises targeted to improve flexibility on performance has not been meet by considerably enough investigation.

Since there are several and various programs. methods and techniques of improving flexibility via muscular stretch. incorrect employment of these methods according to the type of the specialized activity and the athlete's abilities will make the intended benefits difficult to be gained and that was confirmed by Allen W. Jackson (2006) that when needing to improve muscular stretch it would be detailed according to performance requirements in the type of the selected activity due to its remarkable role in defining the final result of different performance forms.

Muscular flexibility classification has been developed to numerous methods and different techniques to increase the motor range via muscular stretch. According to these classifications there are fixed stretch. negative stretch. positive stretch. moving stretch. isometric stretch and stretch through proprioceptive neuromuscular facilitation (PNF) (Brad: 1996).

The fixed stretch is mostly used where the individual stretches a muscle or a specific muscular group slowly for a part of the body in a specific position then getting fixed in that position for a specific time and as for plastic stretch the individual uses muscular contract to make the muscle stretch via a quick stretching movement of the muscle or the selected muscles without rest at some point of the movement quickly with each repetition. Dynamic stretch indicates that it occurs when performing certain movements in different sports. It is similar to the plastic stretch in that both of them uses the quick body movements to stretch the muscle and scientifically. the dynamic stretch is the nearest to perform the required movements in the specialized activity but in a lower intensity. 
The proprioceptive neuromuscular facilitation (PNF) is one of the important training methods containing a number of techniques that contribute to improve the motor range of joints operating in the movement as this method depends on a physiological idea related to functions of organs of motor sensation of muscles where the activity of the organs is inhibited in the muscle to be stretched to reduce the processes of the reversed acts resisting the muscle stretch process leading to increase the joint motor range. This technique is the most effective to improve flexibility. As it depends on the contract- relax process. hence. it is called contractrelax technique. The proprioceptive neuromuscular facilitation has the following methods:

1- Slow reversal contract (SRC).

2- Contract-relax - antagonist - contract (CRAC).

The handball goalkeeper is one of the most important lines or positions of the play in the team. He is the last defensive line and the last position in the team deciding the fate of the attack that ends with shot. He is frequently the first who leads his team attacks and sometimes when the goalkeeper is excellent. he may end the attack with a direct goal throw in the opponent team goal and he may score a goal when the opponent goalkeeper is progressed (Kamal: 1998).

Modern handball needs a goalkeeper of a high physical fitness. Developing the goalkeeper physical properties becomes one of the most important sides in daily. weekly. interval and yearly training plan (Mohammed Khaled: 2008).

Flexibility is one of the essential pillars on which gaining and mastering the motor performance is built for the handball goalkeeper. The goalkeeper who has considerable flexibility of joints and plasticity of muscles makes a lower effort when learning and mastering skills as compared to another goalkeeper who has not the same flexibility of joints and plasticity of muscles. The importance of flexibility of the goalkeeper appears in the following points:

1- It contributes to learning. to mastering and to developing the skill and motor performance quickly for the goalkeeper.

2- It contributes to protecting from injuries related to muscles. tendons and girdles operating on the joint the goalkeeper may expose as a result of performing sudden and swift movements.

3-Developing flexibility of the goalkeeper contributes to improving strength and speed elements and that in turn affects the development and gaining his own motor skill.

4-Reducing the joint motor range affects the amount of power generated to perform the movement optimally e.g.. reducing the goalkeeper shoulder joint motor range may effect on the speed and strength of passing during the fast attack. 
5-Reducing the joint flexibility during the movement leads to increase the burden on the muscle as that needs to generate a greater power to compensate this deficiency to achieve the goal of the movement and consequently. the muscle will suffer from an extra effort that may result in lowering the amount of performance (Kamal: 1998).

Through her reviewing some studies and previous researches (Ahmed: 2016). (Ahmed: 2013). (Khaled: 2013). (Sahar: 2015). (Abdel Razzaq: 2016). (Magda: 2014) and (Videira: 2010) resulted in the importance of flexibility and its effect on developing the skill performance by using stretch exercises for the development of flexibility. the researcher noticed that it would be preferable to detail requirements of handball goalkeepers for flexibility according to the nature of performance where she predicted that this method would provide better chances to improve physical and skill performance together with saving time and effort outlined to develop this important physical feature for goalkeeper performance. The current research is also a practical application and a new technique on which the staff working in the field of handball training depend to improve the skill performance through increasing the motor range of joints operating and this encouraged the researcher to carry out this study to identify the effect of stretch exercises by using PNF techniques on the motor range of joints operating and the level of skill performance of handball goalkeepers.

\section{Research objectives:}

The purpose of this investigation was to know the effect of stretch exercises by using some proprioceptive neuromuscular facilitation (PNF) on the following:

1- The motor range of joints viz. (shoulder. spinal column. trunk. pelvis and foot).

2- The level of skill performance of young female handball goalkeepers born in (2006).

\section{Research hypotheses:}

1- There are statistically significant differences between the pre and postmeasurements of the motor range of joints of (shoulder. spinal column. trunk. pelvis and foot) in favor of the post-measurement.

2- There are statistically significant differences between the pre and postmeasurements of the level of skill performance of young female handball goalkeepers born in (2006) in favor of the post-measurement.

\section{Research plan and procedures:}

Method:

The researcher applied the experimental method of one experimental group by using the pre and post-measurements.

Research people:

They included young female handball goalkeepers born in (2006) and 
enrolled with Egyptian Handball Association in Sports season of 2020/2021.

\section{Research sample:}

It was selected intentionally from young female handball goalkeepers born in (2006) of Zamalek Sporting Club of teams (a). (b) and (c) counting (10) goalkeepers together with young female handball goalkeepers born in (2006) of Al-Ahly Sporting Club of teams (a) and (b) counting (8 goalkeepers) to carry out the research pilot study.

Research sample homogenous:

The researcher insisted on the extent of the normality of the research sample individual distribution in the light of the following variables: growth average (age, height, weight and training age). physical measurements of motor range of joints of (shoulder, spinal column, trunk, pelvis and foot) and the level of skill performance of goalkeepers as shown in Table (1) below:

\section{Table (1)}

Arithmetic mean, standard deviation and skewness coefficient of averages of growth and physical measurements of motor range of joints of (shoulder, spinal column, trunk, pelvis and foot) and the level of skill performance of goalkeepers of the research sample

\begin{tabular}{|c|c|c|c|c|c|}
\hline & variables & Units & $x^{-}$ & SD & $\begin{array}{c}n=18) \\
\begin{array}{c}\text { Skewness } \\
\text { coefficient }\end{array}\end{array}$ \\
\hline \multirow{4}{*}{$\begin{array}{l}\text { Growth } \\
\text { averages }\end{array}$} & Age & yr. & 14.19 & 2.77 & 0.74 \\
\hline & Height & $\mathrm{cm}$. & 163.7 & 2.95 & -0.98 \\
\hline & Weight & kg. & 56.85 & 9.50 & -0.26 \\
\hline & Training age & yr. & 6.5 & 0.5 & 0.6 \\
\hline \multirow{6}{*}{$\begin{array}{l}\text { Physical } \\
\text { variables }\end{array}$} & $\begin{array}{l}\text { Test of flexibility of shoulder joints } \\
\text { from horizontal position }\end{array}$ & $\mathrm{cm}$. & 34.00 & 2.67 & 0.00 \\
\hline & Test of flexibility of spinal column & $\mathrm{cm}$. & 19.60 & 1.07 & 0.28 \\
\hline & Test of stand trunk bend & $\mathrm{cm}$. & 14.40 & 2.37 & -0.13 \\
\hline & $\begin{array}{l}\text { Test of pelvis flexibility (tow feet } \\
\text { apart aside maximally) }\end{array}$ & $\mathrm{cm}$. & 15.30 & 2.58 & 0.35 \\
\hline & $\begin{array}{l}\text { Test of flexibility of foot joint } \\
\text { (grip upward) }\end{array}$ & $\mathrm{cm}$. & 7.65 & 0.25 & 0.6 \\
\hline & $\begin{array}{l}\text { Test of flexibility of foot joint } \\
\text { (grip downward) }\end{array}$ & $\mathrm{cm}$. & 9.81 & 0.41 & 0.07 \\
\hline \multirow{4}{*}{$\begin{array}{l}\text { Skill } \\
\text { variables }\end{array}$} & High arm defense (30 sec.) & rep. & 8.11 & 1.39 & 0.705 \\
\hline & $\begin{array}{l}\text { Arm defense under the shoulder } \\
\text { level }(20 \mathrm{sec} .)\end{array}$ & rep. & 7.49 & 1.079 & -0.54 \\
\hline & High two arms defense (20 sec.) & rep. & 27.56 & 1.32 & -0.16 \\
\hline & $\begin{array}{l}\text { Aside high two arms defense } \\
\text { (20 sec.) }\end{array}$ & rep. & 6.78 & 0.997 & 0.184 \\
\hline
\end{tabular}




\begin{tabular}{|c|c|c|c|c|}
\hline $\begin{array}{l}\text { Two arms defense over the head } \\
\text { level }(30 \mathrm{sec} .)\end{array}$ & rep. & 1.93 & 0.78 & 0.119 \\
\hline Aside high foot defense (20 sec.) & rep. & 7.18 & 1.17 & 0.345 \\
\hline $\begin{array}{l}\text { Two feet defense with a step in the } \\
\text { reverse way }(30 \mathrm{sec} .)\end{array}$ & rep. & 17.09 & 1.164 & 0.634 \\
\hline $\begin{array}{l}\text { Two feet defense with jump } \\
\text { forward ( } 5 \text { balls) }\end{array}$ & score & 0.159 & 0.017 & -0.43 \\
\hline $\begin{array}{l}\text { Two feet balls block after two } \\
\text { funnels touch }(30 \mathrm{sec} .)\end{array}$ & rep. & 10.31 & 0.925 & -0.50 \\
\hline $\begin{array}{l}\text { Arm and foot defense for lower } \\
\text { corners }(30 \mathrm{sec} .)\end{array}$ & rep. & 16.38 & 1.35 & -0.62 \\
\hline $\begin{array}{l}\text { Arm and foot defense and arms } \\
\text { highly aside }(30 \mathrm{sec} .)\end{array}$ & rep. & 11.11 & 1.555 & 0.831 \\
\hline $\begin{array}{l}\text { Jump arm and foot ball block } \\
\text { ( } 6 \text { balls })\end{array}$ & score & 4.67 & 0.798 & -0.16 \\
\hline $\begin{array}{l}\text { Two feet ball block from jump } \\
\text { position ( } 5 \text { balls) }\end{array}$ & score & 4.78 & 0.420 & -1.38 \\
\hline $\begin{array}{c}\text { Lower balls block from two feet } \\
\text { exchange position }(30 \mathrm{sec} .)\end{array}$ & rep. & 6.044 & 0.852 & 0.606 \\
\hline $\begin{array}{c}\text { Star jump two feet ball block } \\
(5 \text { balls })\end{array}$ & score & 4.711 & 0.458 & -0.96 \\
\hline $\begin{array}{c}\text { Fast attack after ball block } \\
\text { movement }(30 \mathrm{sec} .)\end{array}$ & rep. & 2.978 & 0.723 & 0.034 \\
\hline $\begin{array}{l}\text { Join attack after an attacker error } \\
(5 \text { balls })\end{array}$ & sec. & 18.07 & 0.47 & 1.55 \\
\hline $\begin{array}{l}\text { Pass on the wall from open long } \\
\text { sitting }(30 \mathrm{sec} .)\end{array}$ & rep. & 26.40 & 1.698 & 0.530 \\
\hline $\begin{array}{l}\text { Goal throw after a block movement } \\
\qquad(5 \text { balls })\end{array}$ & sec. & 23.22 & 2.35 & -0.13 \\
\hline $\begin{array}{l}\text { Goal throw after an attacker error } \\
\text { ( } 5 \text { balls })\end{array}$ & sec. & 32.64 & 2.46 & 0.451 \\
\hline
\end{tabular}

Data in Table (1) show that all values of skewness coefficient ranges between $( \pm 3)$ meaning that the research group is homogeneous and free from abnormal distributions.

\section{Tools of collecting data:}

\section{Equipment and devices:}

Restameter to measure height $(\mathrm{cm})$, balance to assess weight $(\mathrm{kg})$, measuring tape, graduated ruler, wall steps, wooden benches, divided boxes, legal handball court, legal handballs, funnels, Sweden benches, plates, stopwatch, net to carry the ball, barriers and whistle.

\section{Forms and interview:}

The researcher conducted a reference survey of literatures and previous Arabic and foreign studies specialized in the field of athletic training and handball 
training in general and handball goalkeeper training in particular to outline and to define the most important and suitable tests of flexibility that measure the motor range of joints operating in skills of young female handball goalkeepers. She made a layout of the following:

1- A form to pilot experts' opinion to underline important joints operating in skills of handball goalkeepers.

2- A form to pilot experts' opinion to underline the following:

a. Tests of flexibility of measuring the motor range of the selected joints.

b. Tests of skill performance of young female handball goalkeepers.

c. The extent of suitability of stretch exercises with proprioceptive neuromuscular facilitation method used as well as repetitions, number of groups, suitable rest interval and time distribution of training units.

3- A form to register information of each female player.

\section{III.Physical and skill tests under investigation:}

\section{1- Flexibility tests:}

1- Test of flexibility of shoulder joints from horizontal position.

2- Test of flexibility of spinal column.

3- Test of stand trunk bend.

4- Test of pelvis flexibility (tow feet apart aside maximally)

5- Test of flexibility of foot joint (grip upward).

6- Test of flexibility of foot joint (grip downward).

\section{2- Skill performance:}

1- High arm defense (30 sec.).

2- Arm defense under the shoulder level $(20 \mathrm{sec}$.

3 - High two arms defense (20 sec.).

4- Aside high two arms defense (20 sec.).

5- Two arms defense over the head level (30 sec.).

6- Aside high foot defense (20 sec.).

7- Two feet defense with a step in the reverse way ( $30 \mathrm{sec}$.).

8- Two feet defense with jump forward (5 balls).

9- Two feet balls block after two funnels touch $(30 \mathrm{sec}$.).

10- Arm and foot defense for lower corners (30 sec.).

11- Arm and foot defense and arms highly aside (30 sec.).

12- Jump arm and foot ball block (6 balls).

13- Two feet ball block from jump position ( 5 balls).

14- Lower balls block from two feet exchange position (30 sec.).

15- Star jump two feet ball block (5 balls).

16- Fast attack after ball block movement ( $30 \mathrm{sec}$.).

17- Join attack after an attacker error ( 5 balls). 
18- Pass on the wall from open long sitting (30 sec.).

19- Goal throw after a block movement ( 5 balls).

20- Goal throw after an attacker error.

Table (2)

Percentages of opinions of experts on tests used under investigation

$(\mathrm{n}=10)$

\begin{tabular}{|c|c|c|c|}
\hline Measurements & Tests & Units & $\begin{array}{c}\text { Percentages } \\
(\%)\end{array}$ \\
\hline \multirow{6}{*}{ Flexibility tests } & $\begin{array}{l}\text { Test of flexibility of shoulder joints from } \\
\text { horizontal position }\end{array}$ & $\mathrm{cm}$. & $100 \%$ \\
\hline & Test of flexibility of spinal column & $\mathrm{cm}$. & $100 \%$ \\
\hline & Test of stand trunk bend & $\mathrm{cm}$. & $90 \%$ \\
\hline & $\begin{array}{l}\text { Test of pelvis flexibility (tow feet apart aside } \\
\text { maximally) }\end{array}$ & $\mathrm{cm}$. & $100 \%$ \\
\hline & Test of flexibility of foot joint (grip upward) & $\mathrm{cm}$. & $100 \%$ \\
\hline & Test of flexibility of foot joint (grip downward) & $\mathrm{cm}$. & $100 \%$ \\
\hline \multirow{20}{*}{ Skill tests } & High arm defense (30 sec.) & rep. & $100 \%$ \\
\hline & Arm defense under the shoulder level (20 sec.) & rep. & $80 \%$ \\
\hline & High two arms defense (20 sec.) & rep. & $80 \%$ \\
\hline & Aside high two arms defense (20 sec.) & rep. & $90 \%$ \\
\hline & Two arms defense over the head level (30 sec.) & rep. & $100 \%$ \\
\hline & Aside high foot defense $(20 \mathrm{sec})$. & rep. & $100 \%$ \\
\hline & $\begin{array}{l}\text { Two feet defense with a step in the reverse way } \\
\qquad(30 \mathrm{sec} .)\end{array}$ & rep. & $100 \%$ \\
\hline & Two feet defense with jump forward ( 5 balls) & score & $100 \%$ \\
\hline & $\begin{array}{l}\text { Two feet balls block after two funnels touch } \\
\qquad(30 \mathrm{sec} \text {. })\end{array}$ & rep. & $100 \%$ \\
\hline & Arm and foot defense for lower corners $(30 \mathrm{sec})$. & rep. & $100 \%$ \\
\hline & $\begin{array}{l}\text { Arm and foot defense and arms highly aside } \\
(30 \mathrm{sec} .)\end{array}$ & rep. & $100 \%$ \\
\hline & Jump arm and foot ball block (6 balls) & score & $90 \%$ \\
\hline & Two feet ball block from jump position ( 5 balls) & score & $80 \%$ \\
\hline & $\begin{array}{l}\text { Lower balls block from two feet exchange } \\
\text { position }(30 \mathrm{sec} \text {.) }\end{array}$ & rep. & $90 \%$ \\
\hline & Star jump two feet ball block ( 5 balls) & score & $100 \%$ \\
\hline & Fast attack after ball block movement (30 sec.) & rep. & $100 \%$ \\
\hline & Join attack after an attacker error (5 balls) & sec. & $90 \%$ \\
\hline & Pass on the wall from open long sitting ( $30 \mathrm{sec})$. & rep. & $100 \%$ \\
\hline & Goal throw after a block movement (5 balls) & sec. & $100 \%$ \\
\hline & Goal throw after an attacker error ( 5 balls) & sec. & $80 \%$ \\
\hline
\end{tabular}

Data in Table (2) illustrate percentages of opinions of experts on tests under investigation where the researcher was satisfied with $80 \%$ to accept the test. 


\section{Scientific treatments of tests used in the research:}

\section{They were carried out for tests used on the pilot sample as follows:}

\section{a. Validity:}

The researcher computed it via assessing the validity of differentiation by applying physical and skill tests under investigation on a group of (8) goalkeepers outside of the research sample as illustrated in Table (3).

Table (3)

Significance of differences between differentiated and undifferentiated groups in physical and skill tests under investigation

\begin{tabular}{|c|c|c|c|c|c|c|c|c|}
\hline & \multirow[t]{2}{*}{ Tests } & \multirow[t]{2}{*}{$\begin{array}{c}\text { Uni } \\
\text { ts }\end{array}$} & \multicolumn{2}{|c|}{$\begin{array}{l}\text { Differentiate } \\
\text { d group }\left(\mathrm{n}_{1}\right)\end{array}$} & \multicolumn{2}{|c|}{$\begin{array}{l}\text { Undifferenti } \\
\text { ated group } \\
\left(\mathrm{n}_{2}\right)\end{array}$} & \multirow[t]{2}{*}{$\begin{array}{l}\mathrm{X}_{1}- \\
-\mathbf{X}^{-} 2\end{array}$} & \multirow[t]{2}{*}{$\begin{array}{c}t- \\
\text { values }\end{array}$} \\
\hline & & & $\mathbf{X}^{-}$ & SD & $\mathbf{X}^{-}$ & SD & & \\
\hline \multirow{6}{*}{ 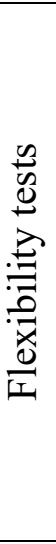 } & $\begin{array}{l}\text { Test of flexibility of shoulder } \\
\text { joints from horizontal position }\end{array}$ & $\mathrm{cm}$ & 31.28 & 0.32 & 36.28 & 0.33 & 5.00 & $3.21 *$ \\
\hline & $\begin{array}{c}\text { Test of flexibility of spinal } \\
\text { column }\end{array}$ & $\mathrm{cm}$ & 18.65 & 0.29 & 22.18 & 0.25 & 3.53 & $3.38^{*}$ \\
\hline & Test of stand trunk bend & $\mathrm{cm}$. & 16.52 & 0.14 & 13.25 & 0.96 & 3.27 & $3.14^{*}$ \\
\hline & $\begin{array}{l}\text { Test of pelvis flexibility (tow } \\
\text { feet apart aside maximally) }\end{array}$ & $\mathrm{cm}$. & 14.65 & 0.21 & 17.63 & 0.14 & 2.98 & $3.29 *$ \\
\hline & $\begin{array}{l}\text { Test of flexibility of foot joint } \\
\text { (grip upward) }\end{array}$ & $\mathrm{cm}$. & 8.56 & 0.87 & 7.10 & 0.21 & 1.46 & $3.87^{*}$ \\
\hline & $\begin{array}{l}\text { Test of flexibility of foot joint } \\
\text { (grip downward) }\end{array}$ & $\mathrm{cm}$. & 8.21 & 0.17 & 10.15 & 0.32 & 1.94 & $3.62 *$ \\
\hline \multirow{10}{*}{ 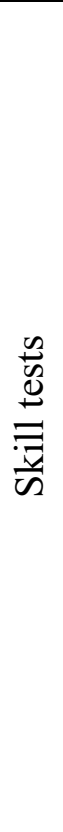 } & High arm defense (30 sec.) & rep. & 10.54 & 0.36 & 9.97 & 0.21 & 0.57 & $5.12 *$ \\
\hline & $\begin{array}{l}\text { Arm defense under the shoulder } \\
\text { level }(20 \mathrm{sec} .)\end{array}$ & rep. & 6.68 & 0.24 & 5.47 & 0.38 & 1.21 & $10.07 *$ \\
\hline & High two arms defense (20 sec.) & rep. & 28.40 & 6.95 & 21.20 & 2.17 & 7.2 & $2.62 *$ \\
\hline & $\begin{array}{l}\text { Aside high two arms defense } \\
(20 \mathrm{sec} .)\end{array}$ & rep. & 6.09 & 0.25 & 5.44 & 0.36 & 0.65 & $5.55^{*}$ \\
\hline & $\begin{array}{c}\text { Two arms defense over the head } \\
\text { level }(30 \mathrm{sec} .)\end{array}$ & rep. & 2.39 & 0.05 & 2.16 & 0.11 & 0.23 & $7.12^{*}$ \\
\hline & Aside high foot defense (20 sec.) & rep. & 8.40 & 0.55 & 7.00 & 1.00 & 1.40 & $2.66^{*}$ \\
\hline & $\begin{array}{l}\text { Two feet defense with a step in } \\
\text { the reverse way }(30 \mathrm{sec} .)\end{array}$ & rep. & 18.60 & 15.2 & 16.00 & 1.41 & 2.60 & $3.20 *$ \\
\hline & $\begin{array}{l}\text { Two feet defense with jump } \\
\text { forward ( } 5 \text { balls) }\end{array}$ & $\begin{array}{c}\text { scor } \\
\mathrm{e}\end{array}$ & 1.80 & 0.84 & 1.20 & 0.45 & 0.60 & $2.52 *$ \\
\hline & $\begin{array}{l}\text { Two feet balls block after two } \\
\text { funnels touch }(30 \mathrm{sec} .)\end{array}$ & rep. & 14.65 & 2.45 & 10.22 & 3.00 & 4.43 & $6.76^{*}$ \\
\hline & $\begin{array}{l}\text { Arm and foot defense for lower } \\
\text { corners }(30 \mathrm{sec} .)\end{array}$ & rep. & 21.20 & 2.17 & 16.20 & 1.30 & 5.00 & $2.65^{*}$ \\
\hline
\end{tabular}




\begin{tabular}{|c|c|c|c|c|c|c|c|}
\hline $\begin{array}{l}\text { Arm and foot defense and arms } \\
\text { highly aside ( } 30 \mathrm{sec} .)\end{array}$ & rep. & 13.20 & 1.92 & 11.00 & 2.45 & 2.20 & $2.01^{*}$ \\
\hline $\begin{array}{l}\text { Jump arm and foot ball block } \\
\text { ( } 6 \text { balls })\end{array}$ & $\begin{array}{c}\text { scor } \\
\mathrm{e}\end{array}$ & 5.65 & 1.43 & 3.86 & 2.77 & 1.79 & $7.86^{*}$ \\
\hline $\begin{array}{l}\text { Two feet ball block from jump } \\
\text { position ( } 5 \text { balls) }\end{array}$ & $\begin{array}{c}\text { scor } \\
\mathrm{e}\end{array}$ & 4.27 & 2.05 & 3.35 & 2.86 & 0.92 & $2.29 *$ \\
\hline $\begin{array}{l}\text { Lower balls block from two feet } \\
\text { exchange position }(30 \mathrm{sec} \text {.) }\end{array}$ & rep. & 7.25 & 1.3 & 5.51 & 2.25 & 1.74 & $8.87^{*}$ \\
\hline $\begin{array}{l}\text { Star jump two feet ball block } \\
\text { ( } 5 \text { balls) }\end{array}$ & $\begin{array}{c}\text { scor } \\
\mathrm{e}\end{array}$ & 4.60 & 3.71 & 4.00 & 4.30 & 0.60 & $2.45^{*}$ \\
\hline $\begin{array}{l}\text { Fast attack after ball block } \\
\text { movement }(30 \mathrm{sec} .)\end{array}$ & rep. & 2.40 & 0.74 & 2.08 & 0.63 & 0.32 & $2.97^{*}$ \\
\hline $\begin{array}{l}\text { Join attack after an attacker error } \\
\text { ( } 5 \text { balls })\end{array}$ & sec. & 17.00 & 3.4 & 32.13 & 4.32 & $\begin{array}{c}15.1 \\
3\end{array}$ & $10.3^{*}$ \\
\hline $\begin{array}{l}\text { Pass on the wall from open long } \\
\text { sitting }(30 \text { sec.) }\end{array}$ & rep. & 26.42 & 2.13 & 20.87 & 1.85 & 5.55 & $7.36^{*}$ \\
\hline $\begin{array}{l}\text { Goal throw after a block } \\
\text { movement ( } 5 \text { balls) }\end{array}$ & sec. & 20.60 & 10.6 & 23.80 & 4.92 & 3.2 & $2.61^{*}$ \\
\hline $\begin{array}{l}\text { Goal throw after an attacker } \\
\text { error ( } 5 \text { balls) }\end{array}$ & sec. & 28.40 & 6.95 & 38.20 & 2.77 & 9.8 & $2.62^{*}$ \\
\hline
\end{tabular}

Tabulated $t$ value at $(0.05)$ significant level $=1.895$.

Data in Table (3) illustrate that there are significant differences between differentiated and undifferentiated female players in physical and skill tests under investigation in favor of differentiated players as all computed $t$ values are greater than those tabulated values at (0.05) significance level meaning that the tests under investigation are valid.

\section{b. Steady:}

The researcher applied the test-retest method where she conducted the first application of tests to the pilot sample on Monday, 20/7/2020 then she applied the same tests once again on Monday, 27/7/2020 with a difference gap of one week between the two applications as shown in Table (4) below:

Table (4)

Correlation coefficients between the first and second applications of physical and skill tests under investigation

\begin{tabular}{|c|c|c|c|c|c|c|c|c|}
\hline \multirow{2}{*}{\multicolumn{2}{|c|}{ Tests }} & \multirow[t]{2}{*}{ Units } & \multicolumn{2}{|c|}{$\begin{array}{c}1^{\text {st }} \\
\text { application }\end{array}$} & \multicolumn{2}{|c|}{$\begin{array}{c}2^{\text {nd }} \\
\text { application }\end{array}$} & \multirow{2}{*}{$\begin{array}{l}\mathbf{X}_{1-}^{-} \\
\mathbf{X}^{-}{ }_{2}\end{array}$} & \multirow{2}{*}{$\begin{array}{c}r- \\
\text { value } \\
s \\
\end{array}$} \\
\hline & & & $\mathbf{X}^{-}$ & SD & $\mathbf{X}^{-}$ & SD & & \\
\hline \multirow{3}{*}{ 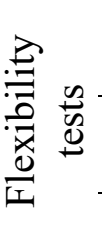 } & $\begin{array}{l}\text { Test of flexibility of shoulder } \\
\text { joints from horizontal position }\end{array}$ & $\mathrm{cm}$. & 34.70 & 2.87 & 34.40 & 3.44 & 0.30 & 0.94 \\
\hline & $\begin{array}{c}\text { Test of flexibility of spinal } \\
\text { column }\end{array}$ & $\mathrm{cm}$. & 19.20 & 0.79 & 19.00 & 0.67 & 0.20 & 0.85 \\
\hline & Test of stand trunk bend & $\mathrm{cm}$. & 15.40 & 1.58 & 15.00 & 1.63 & 0.40 & 0.86 \\
\hline
\end{tabular}




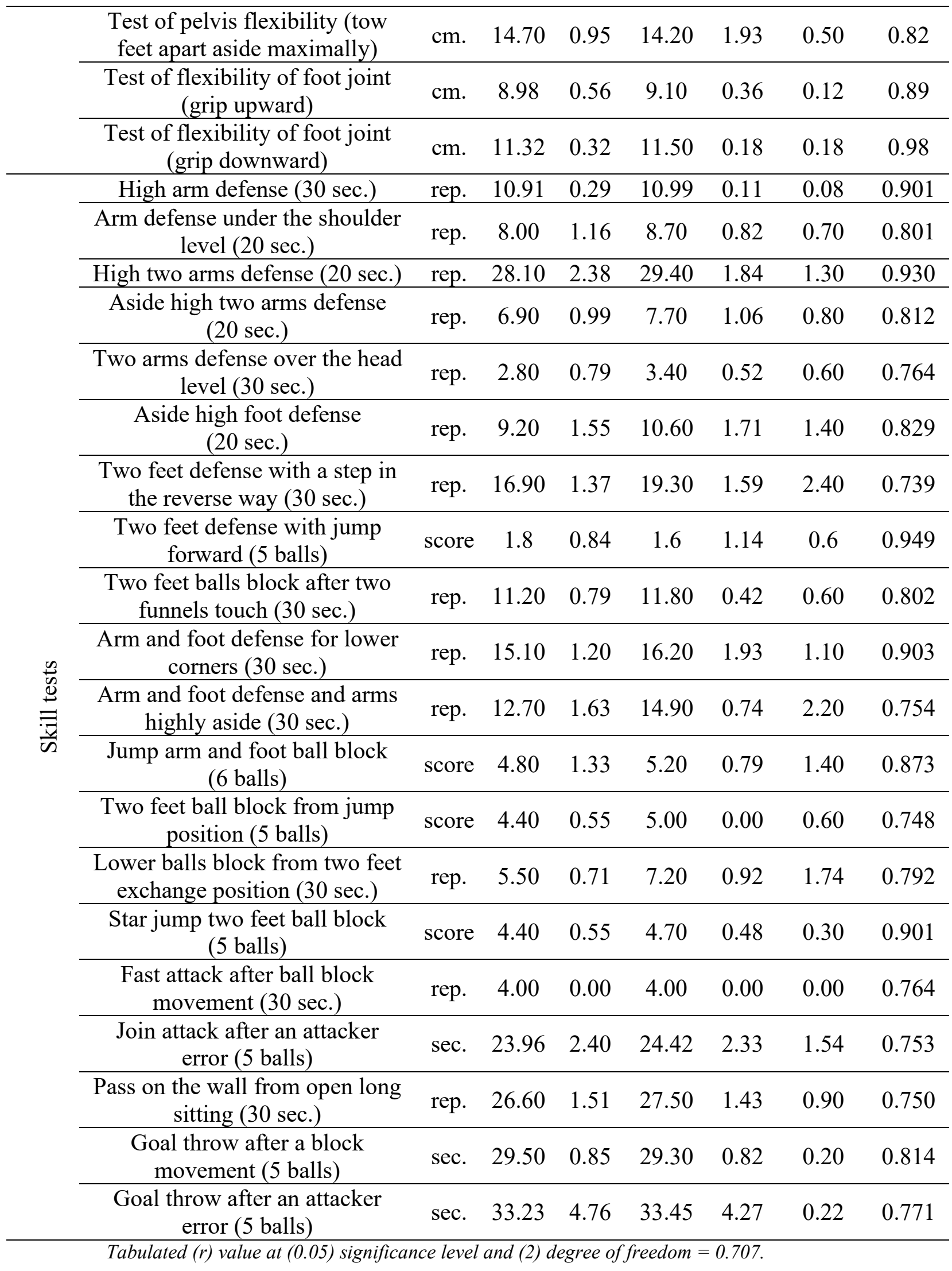


Data in Table (4) indicate that correlation coefficients between the $1^{\text {st }}$ and $2^{\text {nd }}$ applications of physical and skill tests under investigation range from (0.98 to $0.739)$ meaning that such correlation coefficients are significant and hence, the physical and skill tests under investigation are stable.

\section{Layout of the suggested stretch exercises:}

\section{Goal of exercises::}

The purpose of the suggested stretch exercises by using some proprioceptive neuromuscular facilitation (PNF) was as follows:

1- To develop flexibility of joints of (shoulder, spinal column, trunk, pelvis and foot) operating in skills of young female handball goalkeepers.

2- To improve the level of skill performance of young female handball goal keepers.

\section{Fundamentals of setting exercises:}

The researcher considered the following general fundamentals of athletic training:

1- The exercises should be matched with features of the age of the research sample of young female handball goalkeepers born in (2006).

2- The suggested exercises should meet goals for which they have been set and those were to develop flexibility of joints of (shoulder, spinal column, trunk, pelvis and foot) as well as improving the skill level of young female handball goalkeepers.

3- The work for stretching should be directed to consider the nearest form of the skill performance as a fundamental in training units.

4- Scientific fundamentals related to the training load in respect of (time of performance, internal rest intervals, groups and repetitions) should be considered for each training unit.

\section{Preparation of exercises in their initial form:}

The researcher has prepared exercises in their initial form as she defined (51) exercises presented to experts and concluded from experts opinions the following:

- The number of the program units would be (3) training units.

- The number of training sessions would be (3) per week.

- A number of (9) exercises were excluded, hence, the number became (42) exercises in their final form.

In the light of opinions and notes of experts the necessary modifications were made and the program was schemed.

IV. Duration of applying the exercises:

On the basis of the specialized experts opinions in handball training and reviewing scientific references, previous studies and web sites the following pints 
were defined:

- The suggested (PNF) exercises were applied in (3) months i.e. (12 weeks).

- The number of training units was (3).

- The number of training sessions per week was (3).

- The suggested program contained (36) training sessions resulted from (3) training sessions $\mathrm{x}(12)$ weeks.

- The average period of the (PNF) exercises within the training session ranged from (38 to 47) min. Data in Table (5) explain percentages of the experts' opinions.

Table (5)

Percentages of experts' opinions on the duration of application of the suggested (PNF) exercises

\begin{tabular}{|c|c|c|}
\hline Constituents of the suggested program & Duration & $\begin{array}{c}\text { \% of } \\
\text { agreement }\end{array}$ \\
\hline Duration of the program & (3) months & $100 \%$ \\
\hline The number of training sessions per week & $\begin{array}{l}\text { (3) training } \\
\text { sessions }\end{array}$ & $90 \%$ \\
\hline $\begin{array}{l}\text { The Average of (PNF) exercises within the training } \\
\text { session }\end{array}$ & (38 to 47$)$ & $80 \%$ \\
\hline
\end{tabular}

\section{Research executive procedures:}

\section{1- Pilot study:}

The researcher conducted the pilot study on (8) handball goalkeepers from the research people but outside the main research sample from Thursday, $30 / 7 / 2020$ to $3 / 8 / 2020$ for the following purpose:

- To make sure that the suggested program exercises would be suitable for the research sample.

- To discover difficulties that may face application of the training sessions.

- To provide the necessary devices and tools for applying exercises.

- To define the validity of devices and tools being used.

\section{2- Pre-measurements:}

The researcher carried out those measurements for physical and skill variables under investigation as follows:

a- Measuring physical variables under investigation viz. flexibility of two shoulder joints from the horizontal position, flexibility of spinal column, stand trunk bend, flexibility of pelvis and flexibility of two joints of foot on Thursday, 6/8/2020.

b- Measuring the skill variables under investigation viz. (tests of the level of skill performance of young female handball goalkeepers) on Friday, 7/8/2020. 


\section{3- The main experiment:}

- The suggested stretch exercises by using proprioceptive neuromuscular facilitation (PNF) were applied to the main research sample of young female handball goalkeepers born in (2006) at the handball court of Zamalek Sporting Club from Saturday, 8/8/2020 to Saturday, 31/10/2020 for three months of total of (12) weeks by (3) training sessions a week.

- The researcher allotted application of exercises of proprioceptive neuromuscular facilitation (PNF) for handball goalkeepers of teams $(\mathrm{a}, \mathrm{b}, \mathrm{c})$ together as (4 goalkeepers of team a, 3 goalkeepers of team b and 3 goalkeepers of team $c$ ) before time of the main training of the team.

\section{4- Post-measurements:}

The researcher carried out the post-measurements of the research physical and skill variables similar to the pre-measurements on Sunday and Monday, $1 \&$ 2/11/2020.

\section{Statistical treatments being used:}

The researcher applied the (SPSS) statistical program to get statistical results and the following statistical techniques were used:

- Arithmetic mean (X').

- Standard deviation (SD).

- Median.

- Skewness coefficient.

- $t$-test.

- Correlation coefficient.

- Percentage.

\section{Presentation and discussion of results:}

\section{Presentation and discussion of results of physical variables:}

Table (6)

Significance of differences between means of the pre and post-measurements of the research group in physical variables

$(\mathrm{n}=10)$

\begin{tabular}{|c|c|c|c|c|c|c|c|c|}
\hline \multirow[t]{2}{*}{ Physical variables } & \multirow[t]{2}{*}{$\begin{array}{l}\text { Unit } \\
s\end{array}$} & \multicolumn{2}{|c|}{$\begin{array}{c}\text { Pre- } \\
\text { measureme } \\
\text { nt }\end{array}$} & \multicolumn{2}{|c|}{$\begin{array}{c}\text { Post- } \\
\text { measurement }\end{array}$} & \multirow[t]{2}{*}{$\mathbf{X}_{1-}^{-} \mathbf{X}_{2}$} & \multirow{2}{*}{$\begin{array}{c}\text { \% of } \\
\text { improve } \\
\text { ment }\end{array}$} & \multirow[t]{2}{*}{$t$ values } \\
\hline & & $\mathbf{X}$ & SD & $\mathbf{X}$ & SD & & & \\
\hline $\begin{array}{l}\text { Test of flexibility of } \\
\text { shoulder joints from } \\
\text { horizontal position }\end{array}$ & $\mathrm{cm}$ & 39.00 & 2.45 & 33.80 & 2.66 & 5.20 & & $3.29^{*}$ \\
\hline $\begin{array}{l}\text { Test of flexibility of spinal } \\
\text { column }\end{array}$ & $\mathrm{cm}$ & 19.80 & 1.32 & 16.20 & 1.03 & 3.60 & $18.8 \%$ & $3.98^{*}$ \\
\hline Test of stand trunk bend & $\mathrm{cm}$ & 14.20 & 2.66 & 17.90 & 2.08 & 3.70 & $26.06 \%$ & $3.65^{*}$ \\
\hline
\end{tabular}




\begin{tabular}{ccccccccc}
\hline $\begin{array}{c}\text { Test of pelvis flexibility } \\
\text { (tow feet apart aside } \\
\text { maximally) }\end{array}$ & $\mathrm{cm}$ & 15.40 & 2.84 & 11.90 & 1.79 & 3.50 & $22.73 \%$ & $3.45^{*}$ \\
\hline $\begin{array}{c}\text { Test of flexibility of foot } \\
\text { joint (grip upward) }\end{array}$ & $\mathrm{cm}$ & 7.66 & 0.39 & 11.36 & 0.11 & 3.70 & $48.30 \%$ & $3.64^{*}$ \\
\hline $\begin{array}{c}\text { jest of flexibility of foot } \\
\text { joint (grip downward) }\end{array}$ & $\mathrm{cm}$ & 12.69 & 0.15 & 9.85 & 0.21 & 2.84 & $22.38 \%$ & $3.15^{*}$ \\
\hline
\end{tabular}

Tabulated $t$ value at (0.05) significance level $=1.833$

Data in Table (6) show that there are significant differences between the pre and post-measurements of the research experimental group of young female handball goalkeepers born in (2006) in physical variables under investigation in favor of the post-measurement where all computed $t$ values are greater than those of tabulated values at (0.05) significance level and also percentages of improvement range from $(13.33 \%$ to $48.30 \%)$.

The researcher attributes this improvement to the suggested stretch exercises by using the proprioceptive neuromuscular facilitation technique that led to improve physical abilities of players and to increase the motor range of joints (flexibility of the two shoulder joints from the horizontal position, flexibility of spinal column, flexibility of trunk, flexibility of pelvis and flexibility of foot joint) as the program depended on exercises working in all directions allowed by the joint. Also the neuromuscular facilitation technique to improve muscular flexibility depended on variety between moving and stationary muscular contractions allowing the muscular tissue to condition with the nature of any muscular act it carries out.

Also this technique of muscular contraction depends on increasing muscle strength enabling the organ to move positively in the full range of the joint as Kathy Stevens, (2004) confirmed that stretch and strength exercises should be performed in balance and muscular stretch exercises could increase flexibility and this process had a great benefit to increase the amount of strength through applying the proprioceptive neuromuscular facilitation technique and getting a higher level of balance around the joint.

These results matched with those of Dalia Mohammed Marouf, (2011), Sahar Morsi Al-Sayed Morsi, (2015), Ahmed Hamdy Mohammed Khader, (2016) and Abdel Razzaq Al-Metwalli Zyadah, (2016) that the stretch by the proprioceptive muscular facilitation technique proved a great effectiveness on improving the motor range of joints.

The researcher relates this improvement in physical variables under investigation to the suitability of the suggested stretch exercises for the age of players and their continuity in carrying out the program as it is necessary to work to develop flexibility completely and in balance according to requirements of 
performance for handball goal keeping to reach the optimal performance.

Hence, the $1^{\text {st }}$ research hypothesis stating, "there are statistically significant differences between the pre and post-measurements of the motor range of joints of (shoulder, spinal column, trunk, pelvis and foot) operating in skills of young female handball goalkeepers born in (2006)in favor of the post-measurement" is achieved.

\section{Presentation and discussion of results of skill variables:}

Table (7)

Significance of differences between means of the pre and post-measurements of the research group in skill variables $(\mathrm{n}=15)$

\begin{tabular}{|c|c|c|c|c|c|c|c|c|}
\hline \multirow[t]{2}{*}{ Skill variables } & \multirow[t]{2}{*}{ Units } & \multicolumn{2}{|c|}{$\begin{array}{c}\text { Pre- } \\
\text { measurement }\end{array}$} & \multicolumn{2}{|c|}{$\begin{array}{c}\text { Post- } \\
\text { measurements }\end{array}$} & \multirow[t]{2}{*}{$\mathbf{X}_{1-}^{-} \mathbf{X}_{2}$} & \multirow{2}{*}{$\begin{array}{c}\% \text { of } \\
\text { improvement }\end{array}$} & \multirow{2}{*}{$\begin{array}{c}t- \\
\text { values }\end{array}$} \\
\hline & & $\mathbf{X}$ & SD & $\mathbf{X}$ & SD & & & \\
\hline $\begin{array}{l}\text { High arm defense } \\
\quad(30 \mathrm{sec} .)\end{array}$ & rep. & 9.912 & 1.533 & 12.251 & 5.085 & 2.34 & $\% 45.55$ & $2.98^{*}$ \\
\hline $\begin{array}{l}\text { Arm defense under the } \\
\text { shoulder level }(20 \mathrm{sec} .)\end{array}$ & rep. & 7.312 & 1.224 & 8.792 & 1.871 & 1.48 & $20.24 \%$ & $3.176^{*}$ \\
\hline $\begin{array}{l}\text { High two arms defense } \\
(20 \mathrm{sec} .)\end{array}$ & rep. & 19.754 & 3.486 & 28.331 & 4.532 & 8.58 & $43.42 \%$ & $7.194 *$ \\
\hline $\begin{array}{l}\text { Aside high two arms } \\
\text { defense }(20 \text { sec.) }\end{array}$ & rep. & 4.442 & 2.123 & 6.461 & 1.893 & 2.02 & $45.45 \%$ & $3.404^{*}$ \\
\hline $\begin{array}{l}\text { Two arms defense over } \\
\text { the head level }(30 \text { sec.) }\end{array}$ & rep. & 2.461 & 0.910 & 4.312 & 1.224 & 1.85 & $79.16 \%$ & $15.25^{*}$ \\
\hline $\begin{array}{l}\text { Aside high foot defense } \\
(20 \mathrm{sec} .)\end{array}$ & rep. & 7.681 & 1.312 & 8.211 & 0.391 & 0.54 & $38.35 \%$ & $3.23 *$ \\
\hline $\begin{array}{l}\text { Two feet defense with a } \\
\text { step in the reverse way } \\
(30 \mathrm{sec} .)\end{array}$ & rep. & 15.36 & 6.013 & 19.86 & 6.012 & 4.5 & $54.42 \%$ & $4.41 *$ \\
\hline $\begin{array}{l}\text { Two feet defense with } \\
\text { jump forward ( } 5 \text { balls })\end{array}$ & score & 1.319 & 1.313 & 3.219 & 0.581 & 1.9 & $23.59 \%$ & $6.47^{*}$ \\
\hline $\begin{array}{l}\text { Two feet balls block after } \\
\text { two funnels touch } \\
(30 \mathrm{sec} \text {.) }\end{array}$ & rep. & 10.55 & 1.741 & 15.171 & 5.153 & 4.62 & $38.94 \%$ & $5.86^{*}$ \\
\hline $\begin{array}{l}\text { Arm and foot defense for } \\
\text { lower corners }(30 \mathrm{sec} \text {. })\end{array}$ & rep. & 18.442 & 5.542 & 23.97 & 4.952 & 5.53 & $29.98 \%$ & $3.57^{*}$ \\
\hline $\begin{array}{l}\text { Arm and foot defense and } \\
\text { arms highly aside } \\
(30 \mathrm{sec} .)\end{array}$ & rep. & 12.57 & 2.103 & 14.00 & 7.186 & 1.43 & $25.6 \%$ & $6.39 *$ \\
\hline $\begin{array}{l}\text { Jump arm and foot ball } \\
\text { block ( } 6 \text { balls) }\end{array}$ & score & 5.216 & 1.433 & 8.331 & 4.532 & 3.12 & $38.20 \%$ & $3.28 *$ \\
\hline $\begin{array}{l}\text { Two feet ball block from } \\
\text { jump position ( } 5 \text { balls) }\end{array}$ & score & 2.331 & 0.762 & 6.796 & 1.817 & 4.47 & $27.17 \%$ & $5.36^{*}$ \\
\hline
\end{tabular}




\begin{tabular}{ccccccccc}
\hline $\begin{array}{c}\text { Lower balls block from } \\
\text { two feet exchange } \\
\text { position (30 sec.) }\end{array}$ & rep. & 5.453 & 1.682 & 9.754 & 3.486 & 4.30 & $26.25 \%$ & $7.72 *$ \\
\hline $\begin{array}{c}\text { Star jump two feet ball } \\
\text { block (5 balls) }\end{array}$ & score & 4.891 & 1.374 & 7.442 & 5.542 & 2.55 & $27.59 \%$ & $11.38^{*}$ \\
\hline $\begin{array}{c}\text { Fast attack after ball block } \\
\text { movement (30 sec.) }\end{array}$ & rep. & 1.00 & 0.851 & 2.55 & 1.115 & 1.55 & $17.55 \%$ & $2.34 *$ \\
\hline $\begin{array}{c}\text { Join attack after an } \\
\text { attacker error (5 balls) }\end{array}$ & sec. & 30.86 & 7.410 & 26.07 & 8.419 & 4.79 & $15.51 \%$ & $5.84 *$ \\
\hline $\begin{array}{c}\text { Pass on the wall from } \\
\text { open long sitting (30 sec.) }\end{array}$ & rep. & 17.85 & 1.122 & 23.97 & 4.915 & 6.12 & $40.94 \%$ & $8.38 *$ \\
\hline $\begin{array}{c}\text { Goal throw after a block } \\
\text { movement (5 balls) }\end{array}$ & sec. & 24.25 & 5.85 & 18.17 & 5.115 & 6.08 & $49.40 \%$ & $2.09 *$ \\
\hline $\begin{array}{c}\text { Goal throw after an } \\
\text { attacker error (5 balls) }\end{array}$ & sec. & 39.80 & 6.122 & 28.55 & 7.115 & 11.25 & $36.88 \%$ & $5.33 *$ \\
\hline
\end{tabular}

Tabulated $t$ value at (0.05) significance level $=1.833$.

Data in Table (7) indicate that there are significant differences between the pre and post-measurements of the research experimental group in skill variables under investigation in favor of the post-measurement as all computed $t$ values are greater than those of the tabulated $t$ value at $(0.05)$ significance level. Also percentages of improvement range from $(20.24 \%$ to $79.16 \%)$.

The researcher relates such differences that are in favor of the postmeasurements, to the suggested stretch exercises by the proprioceptive neuromuscular facilitation technique and its containing exercises reflected to the level of skill performance and the training program schemed scientifically has the greatest effect on improving the skill abilities of female goalkeepers.

As flexibility is a vital feature to gain skills and a decisive factor in the skill performance of handball goalkeeper skills, it helps achieve an acceptable level of skill learning and mastering the performance. Development of special physical properties has a direct effect and an essential role in the level of effectiveness of physical and skill performance. If the female player lacks such properties, she will be unable to master the required skill performance (Robert: 2001).

Flexibility is one of the physical fitness components that differs from the other components in respect of its correlation with the motor functional system, the other physical characteristics and the skill and planning performance as well. As the development of skill performance is based on a rated amount of flexibility in the majority of physical activities, the range of movement of joints is an essential factor to succeed in such activities in many athletic practices (Abo Al-Ela: 2004), (Nariman: 2003). The results of the current study match with those of Alaa Ahmed Amin, (2004), Mohammed Monir, (2012), Sahar Morsi Al-Sayed Morsi, (2015) and Ahmed Hamdy Mohammed Khader, (2016) indicated that developing the 
flexibility element had a positive effect on improving the numerical level and the skill performance.

These match with Nariman Al-Khatib et al., (2003) in that the skill performance was affected by the motor range of joints involved in the effectiveness of performance.

Nelson, (2005) confirmed that without flexibility, reaching the distinguished skill performance would be impossible in several sports.

Kathy Stevens, (2004) added that exercises of muscular stretch aiming at increasing flexibility would help correct several errors and faults of technical performance and such motor faults could effect in their turn in their turn on lateness and lowering the level in general and thus this is an enough reason to consider muscular stretch programs based on scientific fundamentals.

Also developing flexibility for the handball goalkeeper should be in line with training principles known where flexibility should be general and special and the load covered the fatigue should not reach the stress (Kamal: 1998) that has been considered by the researcher when scheming and applying the suggested stretch exercises by using the proprioceptive neuromuscular facilitation (PNF) technique in respect of defining flexibility of exercises of each joint and the development ran gradually.

Hence, the $2^{\text {nd }}$ hypothesis stating, "there are differences between the pre and post-measurements in the level of skill performance of young female handball goalkeepers born in (2006) in favor of the post-measurement" is achieved.

\section{Conclusions:}

1- Exercises of proprioceptive neuromuscular facilitation (PNF) have a positive effect on improving flexibility of joints of (shoulder, spinal column, trunk, pelvis and foot) operating in skills of handball goalkeepers.

2- Exercises of proprioceptive neuromuscular facilitation (PNF) have a positive effect on improving the level of skill performance of handball goalkeepers.

\section{Recommendations:}

1- Applying exercises of stretch by using the proprioceptive neuromuscular facilitation (PNF) technique to develop the flexibility element in different sports activities.

2- Applying exercises of stretch by using the proprioceptive neuromuscular facilitation (PNF) technique to other ages.

3- The researcher recommended that the suggested exercises be used within the training program of handball goalkeepers.

\section{Arabic references:}

1- Abdel Razzaq Al-Metwalli Zyadah, (2016): Effect of using one of the proprioceptive neuromuscular facilitation techniques on functional efficiency of the upper thigh joint. M.Sc. Thesis, Faculty of Physical Education for Boys, Alexandria University. 
2- Abo Al-Ela Ahmed Abdel Fattah, (2004): Swimming Training for Higher Levels. Dar AlFekr Al-Arabi (Arab Thought House), $4^{\text {th }}$ Ed., Cairo. 6.

3- Ahmed Hamdy Mohammed Khader, (2016): A training program by using some proprioceptive neuromuscular facilitation techniques and its effect on motor range and the level of performance of bow players. M.Sc. Thesis, Faculty of Physical Education for Boys, Banha University.

4- Ahmed Mohi Al-Din Ibrahim, (2013): Effect of a training program to develop muscular strength and flexibility of trunk on the numerical level of dolphin swimmers. Ph.D. Thesis, Faculty of Physical Education, Tanta University.

5- Alaa Ahmed Amin, (2004): A suggested program to develop muscular stretch in young swimmers and its effect on the technical performance and the level of numerical achievement. Ph. D. Thesis, Faculty of Physical Education for Boys, Helwan University.

6- Ali Ali Nasser Al-Ashmaly, 2016): Effect of using functional strength tools on some physical and skill variables in handball goalkeepers in the Republic of Yemen. Ph. D. Thesis, Faculty of Physical Education for Boys, Helwan University, 132.

7- Amr Sayed Hassan Ahmed (2012): Effect of a suggested training program by using qualitative exercises on the physical and skill level in handball goalkeepers. $\mathrm{Ph}$. D. Thesis, Faculty of Physical Education for Boys, Assuit University, 98, 99.

8- Dalia Mohammed Marouf, (2011): Effect of a suggested program for stretch by using some PNF techniques on the motor range of joints operating and the level of performance of slow backward somersault on the floor exercise apparatus. M. Sc. Thesis, Faculty of Physical Education for Girls, Helwan University.

9- Ghada Hosam Al-Din Shaban, (2020): Physical, skill and psychological profile of female handball goalkeepers. M.Sc. Thesis, Faculty of Physical Education for Girls, Helwan University, 183, 189.

10- Hardan Aziz Salman, (2010): Effect of special exercises on performing some essential skills of handball goalkeepers. Journal of Faculty of Physical Education, Baghdad University, 45, 46.

11- Khalid Mohsin Mahmoud, (2013): Effect of a suggested training program to strengthen and flexibility of the shoulder joint in young speed swimmers. M. Sc. Thesis, Faculty of Physical Education for Boys, Helwan University, 287.

12- Christopher Nouris, (2004): Exercises of Flexibility and Fitness. Translated by Khalid AlAmri, Dar Al-Farouq (Al-Farouq House), Cairo, 293.

13- Kamal Darwish et. al., (1998): Goalkeeper in Handball. Markaz Al-Ketab Lelnashr (Publication Book Center), 13, 14, 301, 302.

14- Lila Labib Mahmoud, (1988): Set up a battery of tests for physical and skill performance for young female goalkeepers under 16 years in handball. International Conference of Sciences and Arts of Sport, Faculty of Physical Education, Al-Menia University, 111.

15- Magda Ali Hassan Al-Nagar, (2014): A training program by using some proprioceptive neuromuscular facilitation techniques and its effect on increasing the motor range and the level of performance of some skills of extension in ballet. M. Sc. Thesis, Faculty of Physical Education for Girls, Zagazig University.

16- Mohammed Hassan Allawi; Mohammed Nasr Al-Din Radwan, (2004): Tests f Motor Performance. Dar Al Faker Al-Arabi (Arab Thought House), Cairo, 326, 343, 352.

17- Mohammed Khalid Hamouda; Galal Kamal Salim, (2008): Attack and Defense in Handball. Cairo, 75. 
18- Mohammed Monir Mohammed, (2012): Relative contribution of flexibility of joints to the numerical level of breaststroke and butterfly swimmers. M. Sc. Thesis, Faculty of Physical Education for Boys, Helwan University.

19- Nariman Al-Khatib et. al., (2003): Muscular Stretch. Markaz Al-Ketab Lelnashr (Book Publication Center), Cairo, 19, 385.

20- Omar Mohammed Labib; Aiman Mahrous Sayed, (2009): Karate (Preparation, Performance, Methods of Training). Dar Al-Huda (Al-Huda House), $1^{\text {st }}$ Ed. Al-Menia, 62.

21- Sahar Morsi Al-Sayed Morsi, (2015): Effect of exercises of stretch with proprioceptive neuromuscular facilitation on electrical activity of muscles related to the performance of some skills of artistic gymnastics. Ph. D. Thesis, Faculty of Physical Education for Girls, Alexandria University.

\section{Foreign References}

22- Allen W. Jackson \& et( 2006): Physical activity for health \& fitness, human kinetics, USA,294.

23- Brad Appleton, (1996): Stretching and Flexibility, copyright by Bradford.cs Huyi-ac, il, 21.

24- Hartley \& Brien \& Sandra, (2001) Coaching the Bemate eymnast. Congress - Cataloging, 205.

25- Joke Kekonen \& et. (2006): Acute Muscle stretching inhibits Maximal strength performance, Research Quarterly For Exercise and sport - Vol. 69, No. 4, PP (411 - 415) December.

26- Kathy Stevens, (2004.): A theoretical overview of stretching and flexibility, American Fitness, printed from find articles .COM, located at http://www.findarticales. Com, 23.

27- Nelson (2005): Sports Medicine and physical fitness, Tornio, Italy, PP 49-52, Sept., 295.

28- Robert E. Mcatee, Jeff Charland, (2001): Facilitated Stretching Human kinetics, U.S.A,149.

29- Videira M\& ect (2010): Pre-exercise Static Stretching effect on Leaping Performance in elite rhythmic gymnasts Department for Health Science, University of Molise, Compobassg Italy.

30- Vivian H. Heyward (2000): Advanced Fitness Assessment \& Exercise Prescription, 3 Ed. Human Kinetics - USA Wobert. Mcatee, (1999), 69, 130, 146.

31- 31-Wobert. Mcatee, (1999): Facilitated Stretching, 2nd Human Kinetics, 14.

\section{III.International Web sites references}

32-http://Findarticies.com/p/articles/mi-hb237/is-7-87. 